\title{
Hoax and its Mechanism in Indonesia
}

\author{
Ni Putu Suci Meinarni \\ Informatics Engineering Study Program \\ STMIK STIKOM Indonesia \\ Denpasar, Indonesia \\ sucimeinarni@stiki-indonesia.ac.id
}

\author{
Ida Bagus Ary Indra Iswara \\ Informatics Engineering Study Program \\ STMIK STIKOM Indonesia \\ Denpasar, Indonesia \\ gusari@stiki-indonesia.ac.id
}

\begin{abstract}
Hoax is one of the issue had been arise in the digital world. It is cause serious matter even though it was only (maybe) a joke at the beginning. For some people who see the potential of creating the hoax, there are certain motives such as political affiliation, ideology and the economic factors. In fact, most of the people who is interact in the digital world put their trust and taking attention on it. Netizens should be smarter to trace the truth at first, a good understanding is necessarily needed technically. As a form of violation regarding the use of technology, hoax is an interesting study to be comprehensively reviewed. It takes a practical mechanism through scientific collaboration between the field of law and the field of information technology. The collaboration's aims to analyze some legislation related to the cybercrime from the legal aspects, as well as tracing through digital forensics related to the flow of the hoax itself from the field of information technology.
\end{abstract}

Keywords-hoax; cybercrime; Indonesian cyberlaws; digital forensic

\section{INTRODUCTION}

In a journal there is a discussion about three broad classes of activity: activism, hacktivism, and cyberterrorism. The first category, activism, refers to normal, non-disruptive use of the Internet in support of an agenda or cause. The second category, hacktivism, refers to the marriage of hacking and activism. It covers operations that use hacking techniques against a target's Internet site with the intent of disrupting normal operations but not causing serious damage. The final category, cyberterrorism, refers to the convergence of cyberspace and terrorism. It covers politically motivated hacking operations intended to cause grave harm such as loss of life or severe economic damage. [1]

Cybercrime is a fast-growing area of crime. More and more criminals are exploiting the speed, convenience and anonymity of the Internet to commit a diverse range of criminal activities that know no borders, either physical or virtual, cause serious harm and pose very real threats to victims worldwide. [2] All parties concerned should pay special attention to the rapid and massive development of this cybercrime.

The crime of information technology emerged along with the birth of the information technology revolution. Social interaction that minimizes physical presence, is another feature of the information technology revolution. With this kind of interaction, the deviation of social relationships in the form of evil will adjust its form to that character [3]. One form of deviation of social interaction in the digital world is a hoax. Hoax is simply can be said as a false of announcement spread through cyberspace, with certain motives and predictable and unpredictable results. Hoax in question can be a picture of a joke or content that contains a provocative hatred, even containing things that are radical.

This is become challenges of communication in digital era[4]. Everyone who interacts in the digital world must do the pattern of absorption of information visually and audio-visual. But not everyone who interacts in the digital world has the ability to understand and digest existing content.

The understanding that a person must possess in responding to various hoaxes information will be discussed further in the fourth section of this paper.

\section{METHODS}

The methodology is used in this study using a normativeempirical law methods, because it is a law research aimed at writing regulations that are closely related research at the library that need data that is secondary. This also using theory of social construction approach which is a theory of contemporary sociology its born was based on the combination of the previous of so many social theories. Social construction theory then becomes an independent theory and is being applied in the study everyday life. As a social theory, the social construction is not only applied in empirical study but also explored to the textual study.[5]

\section{HOAX IN INDONESIAN LEGISLATION}

As a serious form of crime, describing hoax-related legislation in digital social interaction is necessary.

\section{A. Definition of Hoax}

The false news or hoax is an information that is not true, but is made as if it is true[6], but neither gossip.

In the jargon, the hoax is "a false alarm about the circulation of a new virus being sent for advertising purposes masked by some companies who have concealed names in the warning message." Sometimes hoax is considered pseudo-virus. False alarms about viruses have become common.[7] In this case the 
virus can be interpreted as a disease that interfere with social interaction in the digital community.

\section{B. The Trigger of the Hoax}

The social network, as a means of communication is a social transformation of the users that integrates multiple communication tools rather than a simple technological change. [8]. Social transformation in social networking gives rise to various communication patterns, one of which is communication pattern that is considered informative. But the information in the communication is not always justified the truth (hoax indication). There are several things that are deliberately informed and lead to hoax actions. Here are the factors that affect the occurrence of hoax, among others:

\section{1) Ideology [9]}

Ideology is the theories that are not oriented to the truth, but on the interests of the proponent. Ideology is also seen as a means of a particular class or social group that has the power to legitimize its power.[10] Hoax in this case can be used as one of the spread media ideology.

2) Political Affiliation [9]

Political interest is one of the promising "commodities" for the hoax proponents. Through hoaxes every political propaganda can be done efficiently, effectively and massively.

3) Economic [9]

In this information era, mass media are oriented more on the industrialization with its emphasize on business aspects. Ideology becomes the entry point to analyze how mass media are produced and reproduced. In the end, the note describes how religion is represented by a media that has been filled with different ideologies.[11] We can imagine the following situation: a company wants to advertise through a false message type's hoax; an Internet user and moreover even untrained occupant of a higher management functions in a company known read the message, believes it and sends it to its entire list of business contacts; secondary recipients of the message see that it has been relayed by a person having an important function and considers it as completely true; message later turns out to be false information and nothing more than a publicity maneuver.[7]

\section{4) Popularity}

Popularity is one of the motives of hoax deployment. This deployment is intentionally done in the framework of selfactualization. Celebrities often use this pattern to improve their existence in the entertainment world, regardless of whether the spread of the news is bad or good. Without aiming to make celebrities a stereotype of popularity, some important figures also sometimes need to do this pattern. How to get attention in this way is well-known in Indonesia as "Pencitraan".

\section{Indonesian Legislation Related to Hoax}

The regulations related to hoax are contained in :

1) Kitab Undang-Undang Hukum Pidana (Indonesian Penal Code)
When a person is suspected of committing a hoax crime, there are several things that need to be underlined regarding the purpose of hoax deployment that meets the following elements [12]:

- Defamation (Act. 310)

- Slander (Act. 311)

- Minor Humiliation (act. 315)

- $\quad$ Cause False Prejudice (Act. 318)

- $\quad$ Defamation to the Death (Act. 320 and 321)

2) Undang-Undang Nomor 19 Tahun 2016 tentang Informasi dan Transaksi Elektronik (Indonesian Legislation concerning Information and Electronic Transaction)

Criminal acts intentionally and without right to disseminate false news that causes consumer losses electronic transactions and disseminate information to cause a sense of hatred or hostility is regulated in Article 28 jo 45 paragraph (2) formulated in 1 complete text as follows:[12]

- Every person intentionally and without right to disseminate false and misleading news resulting in consumer loss in Electronic Transactions shall be liable to a maximum imprisonment of 6 (six) years and / or a fine of not more than Rp 1,000,000,000.00 (one billion rupiah)

- Same punishment in Paragraph (1), every person intentionally and without right to disseminate information aimed at generating a sense of hatred or hostility of certain individuals and / or community groups based on ethnicity, religion, race, and among groups (SARA).

- Undang-Undang Nomor 8 Tahun 1999 tentang Perlindungan Konsumen (Law Protection of the Consumer)

Specifically, the legal regulation on consumer protection has been incorporated into Law No. 8 of 1999. But related to locus (place), the Act is considered not able to accommodate violations related to consumer protection.

\section{FINDING THE HOAX}

This chapter will discuss how to identify hoaxes, digital forensic paths and reporting mechanisms.

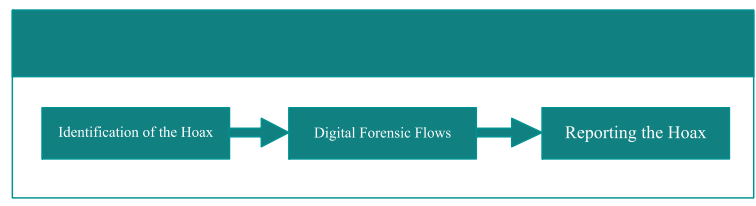

Fig. 1. Finding the Hoax Flows

\section{A. Identify the Hoax}

Identifying hoaxes can be done in various ways. One of them is by looking at the title of news or articles that are disseminated. Titles tend to disadvantage or propagate. In addition to the title we can also identify the address of the web that publish news or articles presented. The web address used in loading news or articles usually uses a web address that can be obtained for free, 
and is easy to obtain without the need for certain conditions, such as the requirement to get a .id domain that must include the identity of the domain owner. In addition to the title of the article and domain or web address, we can also check the photos that accompany the article, with the sophistication of today's technology is very easy for us to be able to know the origin of the photos contained in an article.

\section{B. Digital Forensic Flows}

Checking by using digital forensic method can be done in several ways, namely:

- Using search engines to find out a title or article is actually published in news on other news sites.

- Search the URL or website address, to find out if the web address is presented correctly and credible can be done by looking at the domain used. Checking the domain or website address that contains news or hoax articles can be tracked by looking at who the owner of the domain. Checking can be done by using the identity of the owner whois.net domain name search tool, this website is able to give us information about who the domain buyer we are looking for and also can provide contact person from the admin.

- $\quad$ Search photos on an article identified hoax, searching this photo can be done by utilizing search engines like google photos. Steps to find photos in an original article or have been edited, can by downloading the photo used then input the photo into a google search using photos. There will be seen the photo is an original photo or a photo that has been edited. In addition to using a search with google photos, checking photos can also be done by looking at the metadata of the photo. Metadata checking of photos can be done using Jeffrey's Exif Viewer application [13], this application is able to display the metadata of a photo and be able to tell if the photo is changed or not. In this application there is a type of camera used, the location of the image. In addition to Exif Viewer we can also do more in-depth checking with photos that we use as sample, that is by using the facility from www.wolframalpha.com [14], this web is able to search like weather conditions when the photo we make sample taken. So that way we can know the weather in the area of the photo.

\section{Reporting the Hoax}

Reporting of hoaxes in Indonesia is supported by the government and Masyarakat Anti Fitnah Indonesia (MAFINDO) [15], reporting the hoax there is a portal named turbackhoax.id [16], this portal can be used to report the news or articles that are identified as an hoax. Use of this portal aims to facilitate in identifying hoaxes that spread in cyberspace. To monitor the hoaxes in Indonesia there is also a website that displays hoax statistics circulating in Indonesia. On the website cekhoax.id initiated by MASTEL, THIS and APJII [17].

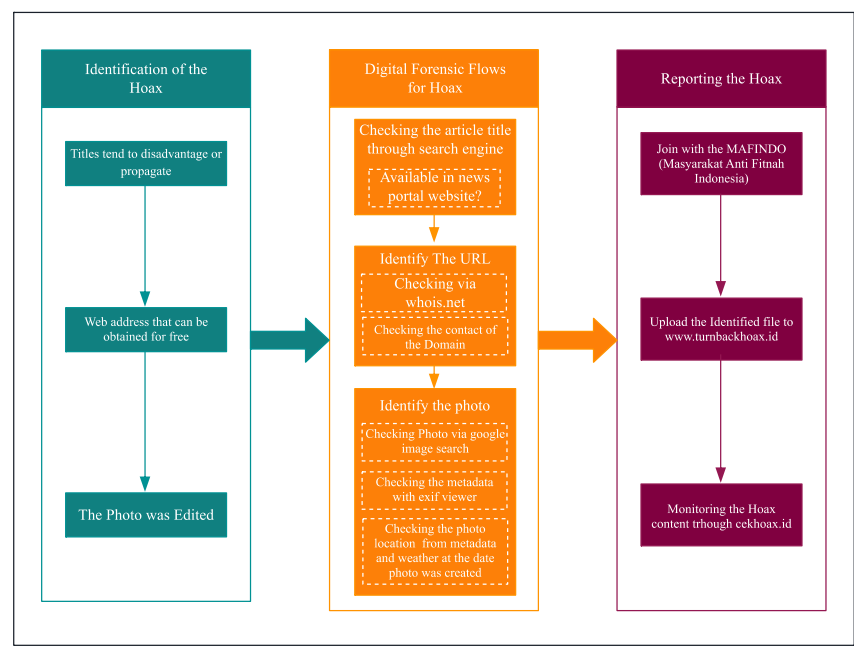

Fig. 2. Detail Workflow Finding and Digital forensic for the Hoax

\section{CONCLUSION}

In responding to various issues contained in the digital world must be through good analysis, so it takes patience and a good understanding of the issue in order to avoid the problems that arise due to the dissemination of hoax news. Although there have been regulations as a legal umbrella of hoax-related crime, as well as government facilities in the form of media reporting, preventive action is a good step that can be done in order to maintain a conducive social social interaction.

\section{ACKNOWLEDGMENT}

We would like to thank to our institution for the motivation and financial support. Especially to LPPM of STMIK STIKOM Indonesia. The support has big meaning to us, and this really motivating us to give better performance in the future.

\section{REFERENCES}

[1] G. E. Curtis, The law of cybercrimes and their investigations. CRC Press, 2012.

[2] Interpol, "Cybercrime / Cybercrime / Crime areas / Internet / Home INTERPOL.” [Online]. Available: https://www.interpol.int/Crimeareas/Cybercrime/Cybercrime. [Accessed June 17, 2018].

[3] H. Djanggih, "Kebijakan Hukum Pidana dalam Penanggulangan Tindak Pidana Cyber Crime di Bidang Kesusilaan,” vol. I, no. 2, 2013.

[4] N. Putu, S. Meinarni, and A. G. Willdahlia, "Communications Skills Of Students Through Electronic Messaging Case Study: Students Of STMIK STIKOM (STIKI) Indonesia,” 2017.

[5] I. B. P. Manuaba, "Memahami Teori Konstruksi Sosial,” Masy. Kebud. dan Polit., 2008.

[6] Wikipedia, "Pemberitaan palsu [False news]." [Online]. Available: https://id.wikipedia.org/wiki/Pemberitaan_palsu. [Accessed May 16, 2018].

[7] G. Ph, "New trends in cyber crime,” pp. 90-95.

[8] S. I. García Medina (Glasgow Caledonian University, Glasgow, UK), P.A. Pereira Correia, Z. González \& R. Contreras-Espinosa (University of Vic, Barcelona, "The role of Facebook as an interactive communication device for business,” Proc. 2014 Int. Conf. ECommerce, E-Bus. E-Service, vol. 1, no. 2014, p. 246, 2014.

[9] @nuonline_ida, “Ideologi, Afiliasi Politik, Ekonomi [Ideology, Political Afiliation, Economy],” Instagram, 2017. 
[10] J. Asshiddiqie, "Ideologi, Pancasila, Dan Konstitusi [Ideology, Pancasila, and Constitution],” 2006.

[11] A. Muttaqin, "Agama dalam representasi ideologi media massa [Religion in the ideological representation of mass media],” J. Dakwah Komun., 2012.

[12] M. K. A. Chazawi, and A. Ferdian, Tindak Pidana Informasi dan Transaksi Elektronik [Criminal Offense of Information and Electronic Transaction], 1st ed. Jakarta: Media Nusa Creative, 2011.

[13] “Jeffrey Friedl's Image Metadata Viewer.” [Online]. Available: http://exif.regex.info/exif.cgi. [Accessed June 10, 2018].

[14] "WolframAlpa Computational Inteligence." [Online]. Available: https://www.wolframalpha.com/. [Accessed June 10, 2018].
[15] R. R. Silalahi, P. Bestari, and W. T. Saputra, "Karakteristik Strategi Crowdsourcing untuk Membatasi Penyebaran Hoaks di Indonesia, Studi Kasus: Masyarakat Anti Fitnah Indonesia [Characteristic of Crowdsourcing Strategy to Limits Hoax Spreadings in Indonesia, Case Study: Indonesian Anti-Defamation Society],” MetaCommunication: J. Commun. Stud., vol. 2, no. 2, 2017.

[16] “Lapor Hoax - TurnBackHoax.” [Online]. Available: http://turnbackhoax.id/lapor-hoax/. [Accessed June 10, 2018].

[17] MASTEL and APJII, “Cekhoax.id Laporan Hoax.” [Online]. Available: http://cekhoax.id/. [Accessed June 10, 2018]. 